Saudi Journal of Business and Management Studies Abbreviated Key Title: Saudi J Bus Manag Stud ISSN 2415-6663 (Print) |ISSN 2415-6671 (Online) Scholars Middle East Publishers, Dubai, United Arab Emirates Journal homepage: https://saudijournals.com

Original Research Article

\title{
Knowledge Core Competence Strategy and Performance of Deposit Money Banks in Rivers State, Nigeria
}

\author{
Dr. E. A. Bestman ${ }^{1 *}$, Gonee Tuanu Sira ${ }^{1}$
}

${ }^{1}$ Department of Office and Information Management, Faculty of Management Sciences, Rivers State University, P.M.B. 5080, Port Harcourt, Nigeria

DOI: $10.36348 /$ sjbms.2022.v07i01.005

| Received: 14.12.2021 | Accepted: 18.01.2022 | Published: 29.01.2022

*Corresponding author: Dr. E. A. Bestman

Department of Office and Information Management, Faculty of Management Sciences, Rivers State University, P.M.B. 5080, Port

Harcourt, Nigeria

\section{Abstract}

This paper examines the relationship between knowledge core competence strategy and performance of Deposit Money Banks in Rivers State, Nigeria. The research design adopted was survey research design through cross sectional design that examined how knowledge core competence strategy enhanced the performance of Deposit Money Banks in Rivers State, Nigeria. The population consisted of seventeen (17) regional Deposit Money Banks in Rivers State, Nigeria. The sample size of one hundred and seventy (170) was determined from the seventeen Regional Deposit Money Banks in Rivers State, Nigeria. This comprises of one (1) top manager, five (5) middle managers, and ten (10) lower managers. One hundred and seventy questionnaire were distributed, while hundred and thirty were retrieved and used for the analysis dues to some irregularities in answering the questions. The collected data was analyzed using the Spearman's Rank Order Correlation Coefficient with the aid of Statistical Package for Social Science (SPSS) within a significance level of 0.05. The findings showed that there is a strong positive relationship between knowledge core competence strategy and performance of Deposit Money Banks in Rivers State, Nigeria. We therefore recommended that Deposit Money Banks in Rivers should implement adequate measures of knowledge core competences which includes; organizational area of interest, skill performance, technology, human capacity or know how that will enhance customers satisfaction and increase patronage of Deposit Money Banks in Rivers State, Nigeria.

Keywords: Knowledge, Core competence, Strategy, Customers satisfaction, Increase patronage, Performance and Deposit Money Banks (MDBs).

Copyright $\odot \mathbf{2 0 2 2}$ The Author(s): This is an open-access article distributed under the terms of the Creative Commons Attribution 4.0 International License (CC BY-NC 4.0) which permits unrestricted use, distribution, and reproduction in any medium for non-commercial use provided the original author and source are credited.

\section{INTRODUCTION}

Deposit Money Banks (MDBs) plays essential role between the Central Banks, businesses and the general public called their customers. Their functions are to ensure customers are able to carry out various transactions within and outside the banks as it happens in the developed countries of the world. Unfortunately, this is not the case in developing nation like Nigeria and Rivers State in particular. Customers queue up in banks to carry out a single transaction, either, cash, electronic transfer and any other banking activities as a result of the absent of knowledge core competence element. Management of the Deposit Money Banks hire cheap labour, outdated technology, combined with poor implementation of processes and procedures and lack of other knowledge core competence capabilities etc.

As resource exploitation and technological competition dominates global businesses, organizations have become performance driven and are constantly seeking for avenues to improve employee performance, individually or as a team, in a bit to survive. This quest for higher employee performance has led organizations to consider alternatives that will increase performance and productivity. One such way is knowledge management (Okwu \& Bestman, 2019). Knowledge core competence is a firm specific organizational signature that leads to market dominance (Uysal, 2007). Knowledge core competence should be built upon 
E. A. Bestman \& Gonee Tuanu Sira., Saudi J Bus Manag Stud, Jan, 2022; 7(1): 41-49

organizational capabilities, and resources. Gaining superiority in a competitive market depends on a firm's ability to identify, developed, deploy, and preserve particular knowledge resources that distinguish it from its rivals (Carmeli and Tishler, 2004) Although, there is no clear differentiation between organizational strategy and knowledge core competence, knowledge core competence is buildup from organizational strategy (Acur, Kandermir, and Boer 2012). Acur, Kandermir, and Boer (2012) opined that knowledge competence strategy must be aligned with the business vision and management must ensure that staff are clearly on board. They must understand why knowledge is important; employees must practice what they preach, they must have channels for discussion and allow a flow of ideas. Good managerial skills alone cannot overcome environmental changes rather knowledge core competence strategy must address them (Lee and Chen, 2012).

Knowledge core competence strategy is organization's unique resources and strengths that management consider when formulating strategy. They reflect the collective learning of the organization, especially in how to coordinate diverse processes and integrate multiple technologies. These include; work force, facilities, market and financial know-how, system and technology. Knowledge reside in the employees as tacit knowledge and in machines and repositories as explicit knowledge, knowledge core competence is the strategic implementation of both tacit and explicit knowledge that gives the organization the competitive edge over others. Information communication technology is now the pace setters for both business and the consumers, it create local and international awareness.

Organizations survive not based on the number of resources they have decided to engage to work for them but based on how productive those resources engaged are in the course of pursuing the organizational goals. Resources that are productive are said to be efficient. Efficient material and human resources create values. Values are created by surmounting challenges and solving problems. Organizational success is the ability of an organization to attain its set goals. The ability of an organization actualizing its set goals depends on capabilities and capacity of its resources. There is a way by which the success of organization is measured. It is measured in terms of performance (Bestman \& Elekwachi, 2019). Today customers are always aware of the current product and services as soon as they entered the market, therefore, organizations that are not able to develop new product and services before others faces the challenges of market completion. The traditional knowledge management, knowledge creation can no longer cope with the high demand from customers, it is a routine activity, and its target is to increase profitability, while profitability is the final output of customer's satisfaction and increase patronage which the traditional method failed to considered. Customers 'satisfaction is key to business performance. Knowledge core competence involves the people best area of interest, organizational infrastructure. Organizations are dynamic, the problem of one organization cannot be used to solve other hence the need for knowledge core competence. Deposit Money Banks in Rivers State has been seriously engaging in strategies that will increase profitability. Profitability is an offshoot of customer's satisfaction and increase patronage. This paper considered those steps that enhanced customer's satisfaction and increase patronage in Deposit Money Banks in Rivers State.

\section{Statement of the Problem}

Deposit Money Banks (MDBs) is one of the important sectors in any nation's economic system. Their operation affects the government, businesses and individuals respectively. Today banks are globalized; it is now possible to do business outside the ambit of a nation economy. Deposit Money Banks are now in serious competition due to the awareness of customers created by information technology and communication. Banks struggling to make profit on a daily bases but their dreams are not coming through. From the various researches cited, no proper investigation has been done in the area of customers' satisfaction and increase patronage. It is obvious the Deposit Money Banks in Rivers State today lacks those basic requirement as a result of the absent of knowledge core competence strategy. They think that acquiring cheap labour and outdated (cheap) information technology and communication tool will enable them to cut cost. This obnoxious strategy has not only resulted in Deposit Money Banks losing their Customers but also, there is a geometrical decrease in patronage, this negates the work of Abratt\&Rusell (1999), they argued that loyalty and retention are the only tool to gain strategic advantage and to be top in the competitive environment, that it is more economical to keep customers than acquiring new one. It is against this backdrop that this study aimed was to investigate how knowledge core competence strategy is crucial to the performance of Deposit Money Banks in Rivers State, Nigeria.

\section{Objective of the Study}

The general objective of this research is to examine how Knowledge core competence enhances the performance of Deposit Money Banks in Rivers State, Nigeria.

\section{Research Questions}

To what extent does Knowledge core competence enhanced performance of Deposit Money Banks in Rivers State?

\section{Research Hypotheses}

In this study, the following Null hypotheses tentatively answered the research questions on Knowledge core competence strategy and Performance 
E. A. Bestman \& Gonee Tuanu Sira., Saudi J Bus Manag Stud, Jan, 2022; 7(1): 41-49

of Deposit Money Banks in Rivers State, Nigeria as follows;

$\mathrm{H}_{01}$ : There is no significant relationship between Knowledge core-competence and Customers' satisfaction of Deposit Money Banks in Rivers State.
$\mathrm{H}_{02}$ : There is no significant relationship between Knowledge core-competence and Increase patronage of Deposit Money Banks in Rivers State.

Conceptualization of Knowledge core-competence Strategy and Performance of Deposit Money Banks in Rivers State

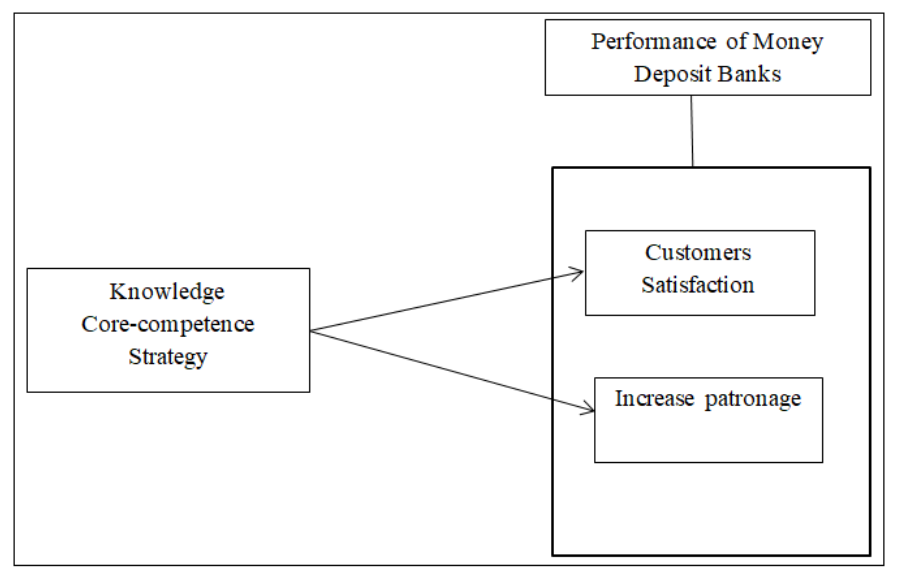

\section{Theoretical Foundation}

Absorptive Capacity Theory by Cohen and Levinthal (1989) is appropriate for the paper. Absorptive capacity is "the ability of a firm to recognise the value of new external information, assimilates it, and apply it to commercial ends". Its tenant relates to the definition of knowledge core competence. They claimed that this was critical for innovativeness. In 1990 they summarized their article from the individual learning context to organizational context. They identified that principle guiding knowledge tends to enhance subsequent learning and competition because memory is associative. At the organizational level they see the acquisition of new knowledge as being mediated by individual gatekeepers and boundary-spanners, and ideally distributed around the organization and possessing diverse expertise and contacts. Over the years the concept has gained popularities in the information system research. Zahra and George (2009) updated it by providing four construct, Acquisition, Assimilation, Transformation and Application. This theory today play a critical role in information management and knowledge management Systems capability literature (Candice and Brian, 2019).

\section{Concept of Knowledge Core Competence}

Knowledge core competency is a specific factor that a business sees as central to the way the company or its employees work. It fulfills three key criteria (Ambrosini and Bowman, 2009). Although it is easy for competitors to imitate, it can be reused widely for many products and markets, It contribute to the end user (consumer's) experienced benefits and the value of the product or service to its customers (Capaldo, Iandoli and Zollo, 2006). A core competency can take various forms, including technical/subject matter know-how, a reliable process and/or close relationships with customers and suppliers. It may also include product development or culture, such as employee dedication, best Human Resource Management (HRM), good market coverage, or continuous improvement over time. Knowledge core competencies are particular strengths relative to other organizations in the industry, which provide the fundamental basis for the provision of added value, it reflect the collective learning of an organization and involve coordinating diverse production skills and integrating multiple streams of technologies (skills). It includes communication, involvement, and a deep commitment to working across organizational boundaries, such as improving crossfunctional teams within an organization to address boundaries and to overcome them (Chen and Chang, 2010). Few companies are likely to build world leadership in more than five or six fundamental competencies.

A knowledge core competency results from a specific set of skills or production techniques that deliver additional value to the customer (Haland and Tjora, 2006). These enable an organization to access a wide variety of markets. Researchers has shown that the Core Competence of the Corporation illustrate that knowledge core competencies lead to the development of core products which can be further used to build many products for end users (Chen and Chang, 2011). It is developed through the process of continuous improvements over the period of time rather than a single large change. To succeed in an emerging knowledge market, it is more important and required to build knowledge core competencies rather than vertical integration. NEC utilized its portfolio of knowledge core competencies to dominate the semiconductor, telecommunications and consumer electronics market (Garavan, and McGuire, 2001). 
E. A. Bestman \& Gonee Tuanu Sira., Saudi J Bus Manag Stud, Jan, 2022; 7(1): 41-49

Knowledge core competence building is an outcome of strategic architecture which must be enforced by top management in order to exploit its full capacity. According to Prahalad and Hamel (1990), knowledge core competencies are the "collective learning across the corporation". Executives should develop a point of view on which knowledge core competencies can be built for the future to revitalize the process of new business creation (Impson, 2002). Developing an independent point of view of tomorrow's opportunities and building capabilities that exploit them is the key to future industry leadership. For an organization to be competitive, it needs not only tangible resources but intangible resources like knowledge core competences that are difficult and challenging to achieve. It is critical to manage and enhance the competences in response to industry changes in the future. Microsoft for example, has expertise in many IT based innovations where, for a variety of reasons, it is difficult for competitors to replicate or compete with Microsoft's knowledge core competences (Centobelli, Cerchione, and Esposito, 2017).

In a bid to achieve cost cutting, quality and productivity, most executives do not spend their time developing a corporate view of the future because this exercise demands high intellectual energy and commitment (Centobelli, Cerchione, and Esposito, 2017). The difficult questions may challenge their own ability to view the future opportunities but an attempt to find their answers will lead towards organizational benefits. Ljungquist (2007) criticize Javidan (1998) competence hierarchy and emphasized that, competence hierarchy apparently is reasonable, but definitions of the associated concepts are not explicitly defined (Ljungquist, 2007). As a remedy, Ljungquist (2007) proposed the knowledge core competence model with empirical and conceptual applications to practitioners. Capabilities, competencies and resources as the dimensions of knowledge core competencies and identified that knowledge core competencies lead to gain a competitive advantage for a firm (Augier and Teece, 2009).

\section{Performance of Deposit Money Banks in Rivers State}

The concept of customers' satisfaction has not had a specific way of measurement, but rather different authors measure the concepts using various parameters (Adewoye, 2013). There are three ways of measuring customer satisfaction and these include a survey where customer feedback can be transformed into measurable quantitative data, focus group or informal where discussions orchestrated by a trained moderator reveal what customers think and informal measures like reading blocs, talking directly to customers. The National Business Research Institute (NBRI, 2009) opine that any of the following parameters can be used in measuring customer satisfaction; service quality, speed of service, pricing, complaints or problems, trust in employees, the closeness of the relationship with contacts in your firm, other types of services needed and positioning in clients' minds (Chidindi, Van Niekerk, and Matiza, 2014).

According to Felix (2010), customer satisfaction is seen as a key differentiator and increasingly has become a key element of business strategy in a competitive market place where businesses compete for customers and that it is a global issue that affects all organizations, regardless of its size, whether profit or non-profit, local or multinational. Customers' satisfaction is a post-choice and behavioural evaluation or judgment of a specific purchase which indicates and precedes particular decisions if such purchase meets and performs below or above customers' expectations (Legris, Ingham and Collerette, 2003).

It has been noted that the higher customers is satisfied the higher financial performance by increasing the loyalty of existing customers, reducing price elasticity, lowering marketing costs through positive word-of-mouth, advertising, reducing transaction costs, and enhancing organization reputation (Legris, Ingham and Collerette, 2003). Customer satisfaction is very important indicator of Deposit Money Banks Performance. It creates sense of belongingness, emotional binding and brand loyalty among company. Customer service is the most powerful stimulant of brand loyalty (Agboola, 2003). Effective customer satisfaction is a veritable tool to increase patronage.

The global banking scenario is currently undergoing radical transformation owing to liberalization, privatization and globalization with measures introduced and controlled by economies of the world (Pasiouras, 2008). Deposit Money Banks in Rivers State has nothing different from afore mentioned situation. The banking sector of Rivers State can be broadly classified into non-scheduled and scheduled banks. Scheduled banks are further categorized as commercial and cooperative commercial banks (Money Deposit Banks). The Deposit Money Banks has been growing due to growing competition, changing demographic profile and increased demand for credit from consumers and industry. The banking industry is highly competitive worldwide (Shen, Liao and Weyman-Jones, 2008). Most bank products are easy to duplicate and when banks provide nearly identical services, they can only distinguish themselves based on price and quality. Therefore, customer satisfaction, loyalty and retention are the only tool to gain strategic advantage and to be top in the competitive environment. It is more economical to keep customers than acquiring new one (Asuquo and Ezekwe, 2020).

Uvais and Sulaman (2017) suggests that patronage is an identified form of switching behavior of the customers and the satisfied customers always 
E. A. Bestman \& Gonee Tuanu Sira., Saudi J Bus Manag Stud, Jan, 2022; 7(1): 41-49

remain patronized to the company they deal with. Asuquo and Ezekwe (2020) concludes that customer satisfaction itself can be identified as the most important sign of patronage intention. Dabiri, Ojenike and Akintan (2017) finds that the behavioral intention is the key to patronage and it can be developed by increasing more satisfied customers by adding value to the services delivered.

Patronage is the impulse desire and consideration within the consumer or customer which induce the purchase of goods from certain outlet or company (Adiele and Opara, 2014). The consumers' purchase intention is an essential index to predict consumer behaviour as a subjective attachment to the product. Adiele and Opara, (2014) states that customer patronage is defined as a situation when the customer wishes to consider, recommend, or make purchases from retailers in the future, the desire to buy from it, and the willingness to recommend to others in the future. Companies are to invest in relationship building and customer intimacy with loyal customers as it will in turn lead to stronger loyalty (Powei, Adebiye and Temitope, 2018).

\section{METHODOLOGY}

The research design is a basic plan that guides the collection and analysis phase of the research. It provides the framework that specifies the type of information to be collected, its sources and collection and the tools that will be effective for analysis. The research design adopted in this study was the cross sectional survey approach. This is used because the respondents are required to complete the questionnaire given to them based on the current trend of Knowledge core-competence strategy and Performance of Deposit Money Banks in Rivers State, Nigeria. The respondents are selected from the regional Deposit Money Banks in Rivers State using the Simple Random Sampling Techniques. Descriptive Statistics was used for Demographic analysis. This helps the researcher to classify the categories of respondents based on population size. It ascertained the true categories of the population and how it affects the study. It is imperatively used for a wide range of policy decision that affects the study population. The population of this study consists of the seventeen Deposit Money Banks in Rivers State, Nigeria. It specifically covers the Top Management, Middle and Lower Management of the Deposit Money Banks in Rivers State.

\section{Data Analysis and Results Univariate Analysis (Descriptive Statistics)}

This section answered the research questions to what extent does knowledge core competence strategy enhances organizational performance of Deposit Money Banks in Rivers State, Nigeria. The descriptive analysis is measured on a 4-point Likert Scale as shown in the table below.

Table 1: Knowledge core competence respondents' Rate

\begin{tabular}{|l|l|l|l|l|}
\hline Items & N & Sum & Mean & $\begin{array}{l}\text { Std. } \\
\text { Deviation }\end{array}$ \\
\hline $\begin{array}{l}\text { To what extent does your bank Core competencies relate to the } \\
\text { development of potential of creating new product lines, technologies and } \\
\text { expansion to new domestic and foreign markets }\end{array}$ & 130 & 369.00 & 2.8385 & .88750 \\
\hline $\begin{array}{l}\text { Banks initiates Knowledge core competence that moderates knowledge- } \\
\text { creation process, and increases unique skill and resources. }\end{array}$ & 130 & 395.00 & 3.0385 & .82032 \\
\hline $\begin{array}{l}\text { To what extent is dynamic capabilities, skills, technology integrated and } \\
\text { build internal and external abilities that functions efficiently in a } \\
\text { dynamically changing environment }\end{array}$ & 130 & 382.00 & 2.9385 & .89576 \\
\hline $\begin{array}{l}\text { To what extent does implementing mechanism that enhanced feedback, } \\
\text { and communication (blog, suggestion box) increases employees and } \\
\text { customers relationship? }\end{array}$ & 130 & 372.00 & 2.8615 & .92136 \\
\hline Valid N (listwise) & 130 & & & \\
\hline
\end{tabular}

Source: Field survey, 2021

Table 1 showed how the banks are able to strategize in their area of Core Competence. Question one shows that the respondent accepted that Core competence relates to the development of potential creating of new product lines and technologies and expansion to new domestic and foreign markets with a calculated mean of 2.84., question two shows that the Banks initiates Knowledge core competence that moderates knowledge-creation process, and increases unique skill and resources with a mean of 3.04, dynamic capabilities, skills, technology integrated and build internal and external abilities that functions efficiently in a dynamically changing environment with a mean of 2.93 and lastly question four, implements mechanism that enhanced feedback, communication (blog, suggestion box) that the bank sees as central to its employees and customers relationship with a mean of 2.86 . 
E. A. Bestman \& Gonee Tuanu Sira., Saudi J Bus Manag Stud, Jan, 2022; 7(1): 41-49

Table 2: Customers satisfaction respondents' rate

\begin{tabular}{|l|l|l|l|l|}
\hline ITEMS & N & Sum & Mean & $\begin{array}{l}\text { Std. } \\
\text { Deviation }\end{array}$ \\
\hline To what extent does your bank increase service quality & 130 & 372.00 & 2.8615 & .92136 \\
\hline To what extent are customers easily attended to per transaction & 130 & 427.00 & 3.2846 & .92539 \\
\hline $\begin{array}{l}\text { How satisfactorily are customers with the bank charge per transfer } \\
\text { (deposit and withdrawal) }\end{array}$ & 130 & 395.00 & 3.0385 & .82032 \\
\hline $\begin{array}{l}\text { To what extent are Customers' ready to continue banking with your banks } \\
\text { as a result of services rendered. }\end{array}$ & 130 & 395.00 & 3.0385 & .82032 \\
\hline Valid N (listwise) & 130 & & & \\
\hline
\end{tabular}

\section{Source: Field survey, 2021}

Table 2 showed that customers are satisfied as a result of proper integration of Knowledge core competence strategy. Question one showed that the respondents indicates that, there is increased service quality with a mean of 2.86 , question two showed that customers are easily attended to per transaction with a mean of 3.28., question three supported that customers are satisfied with the bank charge per transfer (deposit and withdrawal) with a mean of 3.03 and lastly question four also showed that customers' ready to continue banking with the banks as result of the services rendered with a calculated mean of 3.03 respectively.

Table 3: Increase Patronage respondents' rate

\begin{tabular}{|l|l|l|l|l|}
\hline ITEMS & $\mathbf{N}$ & Sum & Mean & $\begin{array}{l}\text { Std. } \\
\text { Deviation }\end{array}$ \\
\hline $\begin{array}{l}\text { Kindly rate the positive switching behavior of the customers to continue } \\
\text { banking with your bank }\end{array}$ & 130 & 382.00 & 2.9385 & .89576 \\
\hline To what extent can you rate the return on investment for the past one year & 130 & 372.00 & 2.8615 & .92136 \\
\hline $\begin{array}{l}\text { To what extent do you believe that a customers' can recommend your bank } \\
\text { to friends and relative as a result of effective service. }\end{array}$ & 130 & 427.00 & 3.2846 & .92539 \\
\hline To what extent does customers maintained loyalty with your bank. & 130 & 395.00 & 3.0385 & .82032 \\
\hline Valid N (listwise) & 130 & & & \\
\hline
\end{tabular}

\section{Source: Field Survey, 2021}

Table 3 showed that implementing effective Knowledge core competence strategy does increase patronage of Deposit Money Banks in Rivers State, Nigeria. Question one showed that respondents indicated that there is positive switching behavior of the customers to continue banking with the banks with a mean of 2.94., question two showed that there is high return on investment with a mean of 2.86 ., question three agreed that customers always recommend friends and relatives with a mean of 3.28 and lastly question four supported that there is a high level of loyalty with a mean of 3.04 .

\section{Bivariate Analysis}

This section showed the relationship between the independent variables and the dependent variables, Knowledge core competence strategy and Performance of Deposit Money Banks in Rivers State, Nigeria.

Table 4: Relationship between Knowledge core competence and Customers satisfaction

\begin{tabular}{|c|c|c|c|c|}
\hline & & & $\begin{array}{l}\text { Knowledge core- } \\
\text { competence }\end{array}$ & $\begin{array}{l}\text { Customers } \\
\text { Satisfaction }\end{array}$ \\
\hline \multirow[t]{6}{*}{$\begin{array}{l}\text { Spearman's } \\
\text { rho }\end{array}$} & \multirow[t]{3}{*}{$\begin{array}{l}\text { Knowledge } \\
\text { Core-competence }\end{array}$} & $\begin{array}{l}\text { Correlation } \\
\text { Coefficient }\end{array}$ & 1.000 & $.948^{* *}$ \\
\hline & & Sig. (2-tailed) & . & .000 \\
\hline & & $\mathrm{N}$ & 130 & 130 \\
\hline & \multirow[t]{3}{*}{$\begin{array}{l}\text { Customers } \\
\text { satisfaction }\end{array}$} & $\begin{array}{l}\text { Correlation } \\
\text { Coefficient }\end{array}$ & $.948^{* *}$ & 1.000 \\
\hline & & Sig. (2-tailed) & .000 & . \\
\hline & & $\mathrm{N}$ & 130 & 130 \\
\hline
\end{tabular}

\section{Source: SPSS Output Version 23.0}

Table 4 showed the relationship between Knowledge core-competence and Customers Satisfaction of Deposit Money Banks in Rivers State, Nigeria. The Correlation coefficient between
Knowledge core competence strategy and Customers satisfaction was significant, $(r=0.948)$ above the average of correlations coefficient, $(r=0.5)$. The probability of correlation $(\rho=0.01<0.05)$. This showed 
E. A. Bestman \& Gonee Tuanu Sira., Saudi J Bus Manag Stud, Jan, 2022; 7(1): 41-49

that there is a positive significant relationship between Knowledge core-competence strategy and Customers satisfaction of Money Deposit Bank in Rivers State, Nigeria

Table 5: Relationship between Knowledge core competence and Increase patronage

\begin{tabular}{|l|l|l|l|l|}
\hline \multicolumn{2}{|l|}{} & $\begin{array}{l}\text { Knowledge } \\
\text { core-competence }\end{array}$ & Increase patronage \\
\hline \multirow{3}{*}{ Spearman's rho } & $\begin{array}{l}\text { Knowledge core- } \\
\text { competence }\end{array}$ & Correlation Coefficient & 1.000 & $.968^{* *}$ \\
\cline { 3 - 5 } & Sig. (2-tailed) &. & .000 \\
\cline { 2 - 5 } & $\mathrm{N}$ & 130 & 130 \\
\cline { 2 - 5 } & Increase patronage & Correlation Coefficient & $.968^{* *}$ & 1.000 \\
\cline { 3 - 4 } & Sig. (2-tailed) & .000 &. \\
\cline { 3 - 4 } & $\mathrm{N}$ & 130 & 130 \\
\hline
\end{tabular}

Source: SPSS Output Version 23.0

Table 5 showed the relationship between Knowledge core-competence and Increase patronage of Deposit Money Banks in Rivers State, Nigeria. The Correlation coefficient between Knowledge core competence strategy and Increase patronage was significant, $(r=0.968)$ above the average of correlations coefficient, $(r=0.5)$. The probability of correlation $(\rho=$ $0.01<0.05)$. This showed that there is a positive significant relationship between Knowledge corecompetence strategy and Increase patronage of Money Deposit Bank in Rivers State, Nigeria

\section{DISCUSSION OF FINDINGS}

In this study, Descriptive and Correlations is used to analyze the concept of Knowledge core competence strategy and Performance of Deposit Money Banks in Rivers State, Nigeria. The results showed that there is a significant positive relationship between Knowledge core competence strategy and Performance of Deposit Money Banks in Rivers State, Nigeria. There is a clear indicator that increasing the various elements of knowledge core competence in Money Deposit Bans in Rivers State, Nigeria, there will a corresponding increase in customers' satisfaction and patronage. This research supports the work of other researchers. Knowledge core competence is developing an independent point of view of tomorrow's opportunities and building capabilities that exploit them is the key to future industry leadership, for an organization to be competitive, it needs not only tangible resources but intangible resources like knowledge core competences that are difficult and challenging to achieve; It enables Deposit Money Banks to strategize in their area of interest. They are able to develop potential that creates new product lines and technologies, expansion to new domestic and foreign markets. The research showed that it is a unique resource that increases customer's satisfaction and patronage. The Money Deposits Banks in Rivers State, Nigeria are able to make profit because, customers' satisfaction which is the key to profitability is considered first. The banks integrate dynamic capabilities, skills, and build internal and external abilities that are efficient in a dynamically changing environment.

This analysis supports the research of Ambrosini and Bowman (2009) which opened that Knowledge core-competence relates to the development of a company, especially to their potential of creating new product lines and technologies and expansion to new domestic and foreign markets. And also the research of Chen and Chang (2010), it is the creator of final products or technology availability; it enhances communication, involvement, and a deep commitment to working across organizational boundaries, such as improving cross-functional teams within an organization to address boundaries and to overcome.

\section{SUMMARY}

This research showed that Knowledge core competence is a critical step or action plans taken to improve customer's satisfaction and increase patronage especially in a global, dynamic and challenging economic system like Rivers State, Nigeria. Adopting Knowledge core competence will enhance organizational dynamic capabilities, enables employees to develop their skills, build internal and external abilities that are efficient in a dynamically knowledge economy.

\section{CONCLUSION}

Knowledge core competence is an effective tool that focuses on customers need, review the current product and services in a global market. It uses the best and current infrastructure, best skill, process and procedure. From the literature reviewed and analysis. It is clear that Knowledge core competence enhanced the performance of Deposit Money Banks in Rivers State, Nigeria.

\section{RECOMMENDATIONS}

Based on literature reviewed and the results of the analysis, Knowledge core competence is a veritable tool for enhancing the performance of Deposit Money Banks in Rivers State, Nigeria. We therefore make the 
E. A. Bestman \& Gonee Tuanu Sira., Saudi J Bus Manag Stud, Jan, 2022; 7(1): 41-49

following recommendation to enhance the performance of Deposit Money Banks in Rivers State, Nigeria.

1. Deposit Money Banks in Rivers State should implement those elements of knowledge core competence that will handle the banks specific areas of interest that will enhance customers Satisfaction and Increase Patronage.

2. Before investing in information technology infrastructure, Deposit Money Banks should consider its impacts on the customers first.

3. Banks should acquire knowledgeable employees (competence staff) that has the necessary capabilities and not to acquires cheap labour in order to cut down cost.

4. Banks should research on the current trend in information technology and communication to gain competitive edge before their competitors.

\section{REFERENCES}

- Acur, N, Kandermir, D., \& Boer, H. (2012). Strategic alignment and new product development: Drivers and performance effects, Journal of product innovation management, 29, 304-318.

- Adewoye, J. O. (2013). Impact of mobile banking on service delivery in Nigerian commercial banks. International review of management and business research, 2(2), 333-334.

- Adiele, K. C., \& Opara, B. C. (2014). Analysis of corporate identify on customer patronage of Banks in Nigeria. International reviews of management and business research, 3(4), 1809-1818.

- Agboola, A. A. (2003). Impact of Electronic Banking on Customer Services in Nigeria. Journal of social sciences, 7(1), 29-36.

- Asuquo, B., \& Ezekwe, C. (2020). Electronic banking service and customers' satisfaction in Deposit Money Banks in Rivers State, Nigeria. Journal of economic and finance, 11(4), 5359.

- Augier, M. \& Teece, D. J. (2009). Dynamic capabilities and the role of managers in business strategy and economic performance. Organizational science, 20, 410-421

- Ambrosini, V., \& Bowman, C. (2009). What are dynamic capabilities and are they a useful construct in strategic management? International journal of management, 11(1), 29-49.

- Bestman, A. E., \& Elekwachi, H. N. (2019). Business intelligence system strategies and organizational success in public hospitals in Rivers State, Nigeria. European Journal of Business and Innovation Research, 7(2), 1-21.

- Capaldo, G., Iandoli, L., \& Zollo, G. (2006). A situationalist perspective to competency management. Human Resource Management: Published in Cooperation with the School of Business Administration, The University of Michigan and in alliance with the Society of Human Resources Management, 45(3), 429-448.
- Centobelli, P., Cerchione, R., \& Esposito, E. (2017). Knowledge management in Startups: Systematic literature review and future research agenda. Sustainability, 9, 361.

- Chen, H. M., \& Chang, W. Y. (2011). Core competence. From a strategic human resource management perspective. African journal of business management, 5(14), 5738-5745.

- Chen, H. M., \& Chang, W. Y. (2010). The essence of the competence concept: Adopting an organization's sustained competitive advantage viewpoint. Journal of organizational management, 16(5), 677-699.

- Chidindi, S., Van Niekerk, J. T., \& Matiza, T. (2014). Perceptions of Electronic Banking Services by Clients in Limpopo Province of South Africa. Mediterranean journal of social sciences, 5(10), 253-267.

- Cohen, W. M., \& Levinthal, D. A. (1989) 'Innovation and learning: The two face of research and development. The economic journal, 99, 569596.

- $\quad$ Dabiri, M. A., Ojenike, J. O., \& Akintan, I. (2017). Perceived service quality and Customer's patronage of selected Banks in Abeokuta, Ogun State, Nigeria. The research journal, 3 -9.

- Felce, A. (2010). Towards a context-engaged approach to work-based learning", Learning and Teaching in Higher Education, 4(1), 20-35.

- Garavan, T. N., \& McGuire, D. (2001). Competencies and workplace learning: Some reflections on the rhetoric and the reality. Journal of workplace Learning, 13(4), 144-163.

- Haland, E., Tjora, A. (2006). Between asset and process: Developing competence by implementing a learning management system. Human resources relations, 59(7), 993-1016.

- Impson, B. (2002). The knowledge needs of innovating organizations. Singapore Management review, 24(3), 51-60.

- Lee, M., \& Chen, T. (2012). Revealing themes and trends in knowledge management: From 1995 to 2010, Knowledge-Based Systems, 28, 47-58.

- $\quad$ Legris, P., Ingham, J., \& Collerette, P. (2003). Why do people use information technology? A critical review of the technology acceptance model. Information \& management, 40, 191-204.

- Pasiouras, F. (2008). Estimating the technical and scale efficiency of Greek commercial banks: The impact of credit risk, off balance sheet activities and international operations. Research in international business and finance, 22(3), 301-318.

- $\quad$ Powei, M. W., Adebiye, J. A., \& Temitope, M. W. (2018). Efficiency, customers' satisfaction and deposit money banks performance in Nigeria. Journal of economic and management, 31(1), 135146.

- Okwu, H. E., \& Bestman, A. E. (2019). Apprenticeship tacit knowledge transfer and team 
performance in oil and gas producing companies in Rivers State, Nigeria. IOSR Journal of Business and Management (IOSR-JBM), 21(11), 1-8.

- Shen, Z., Liao, H., \& Weyman-Jones, H. (2008). Cost efficiency analysis in banking industries of ten Asian countries and regions. Journal of Chinese economics and business studies, 7(2), 199-218.

- Uysal, G. (2007). Core competence: A competitive base for organizational success. Journal of global management, 1(1), 5-16.

- Carmeli, A., \& Tishler, A. (2004). Resources, capabilities, and the performance of industrial firms. A multivariate analysis. Management and decision economics, 25, 299-315.

- Uvais, M., \& Sulaman, E. (2017). Influence of service quality on customers' patronage intention in commercial banks. An empirical evidence. Journal of business and management, 19(6), 62-66.

- Zahra, S. A., \& George, G. (2009). Absorptive capacity: A review, reconceptualization, and extension. Academy of management review, 27(2), $185-203$ 